International Journal of Social Science And Human Research

ISSN(print): 2644-0679, ISSN(online): 2644-0695

Volume 04 Issue 12 December 2021

DOI: $10.47191 /$ ijsshr/v4-i12-43, Impact factor-5.586

Page No: $3768-3772$

\title{
English Language Proficiency and School Performance in English
}

\author{
Sheila Mae O. Cantara ${ }^{1}$, Mary Jane V. Esimos ${ }^{2}$, Leizel B. Francisco ${ }^{3}$, Shelly Joy S. Jungco ${ }^{4}$, \\ Marissa C. Limson ${ }^{5}$, Audrey Karyl P. Maligang ${ }^{6}$, Lennie S. Malubay ${ }^{7}$ \\ 1,2,3,4,5,6,7 Northern Iloilo Polytechnic State College, Estancia, Iloilo Philippines
}

\begin{abstract}
This study determined the English Language Proficiency and School Performance in English as well the school performance as a whole. The respondents of the study were both English teachers and grade 10 students in the national high schools in the fifth district of Iloilo, using the descriptive comparative approach. Findings of which served as basis for the enhancement of the existing English manual used in English 101 for the improvement of English language proficiency of the students enrolled in the said subject. Generally, seventy percent of the student and teacher respondents were female. Teachers' Level of English language proficiency has a significant effect on the level of proficiency of students which has a direct relationship on the school performance. It was also found out that teachers' performance has no significant relationship with the students' performance in English and school performance as a whole. Further, student-respondents performance has a significant relationship with their level of English language proficiency which has a direct effect on the school performance as a whole. The English teachers' performance is related to their English proficiency level, but not associated with the students' performance in English and school performance. However, the English teachers' level of English language proficiency significantly affects the students' level of English proficiency, while the students' performance has a significant effect on their level of English language proficiency, affecting the school performance as a whole. Enhancement of the English language manual that will be used in English 101 (Study and Thinking Skills) must be adopted. Training \& Development Program Design for the Enhancement of English Teachers language Proficiency must be implemented.
\end{abstract}

KEYWORDS: Language, proficiency, performance, enhancement, development

\section{INTRODUCTION}

In this generation where global competition exists, the English language proficiency - the global language - is deemed necessary. In the Philippines where English is an official language for communication and instruction, teachers need to assess the English performance of their students and consider their English language proficiency, such as correct usage, sentence structure, and appropriate subject verb agreement.

The label that the Philippines is the third English-speaking country no longer holds water today (Molina-Lauz, 2010). This competitive advantage of the Philippine is fast diminishing with the decreasing level of English proficiency, especially among the younger generation ( The Chamber of Commerce, 2010), however, existing federal education legislation state education staff, and academicians have set forth general and consistent parameter for defining limited proficiency and fluent English proficiency (Molina-Lauz, 2010).

At Northern Iloilo Polytechnic State College, the English Department is giving the English Proficiency Test (EPT) for the purpose of identifying who among the incoming first year college students are and not ready to take higher English, particularly English 101 (Study and Thinking Skills). Those who are not qualified to take higher English must undergo intensive grammar course (English Plus) to help them out in their grammar difficulty.

The EPT is a measure of the student's learning in high school English where grammar and grammaticality are to be learned at their best. The said test is composed of four test categories, namely: correct usage, identifying errors, vocabulary and reading comprehension.

The examiner have found out that most test takers got very low scores on both correct usage, identifying errors and vocabulary tests respectively, and that they could not even make it half way.

Most of the respondents got failed than passing the EPT test because of this result, they failed in EPT and that they were made to enroll in English Plus which covers intensive grammar to assist them in their grammar difficulty.

This study was anchored on the grammatical competence of Dell Hymes which was originally derived from Noam Chomsky's widely known dichotomy of competence and performance. For Hymes, Chomskyees linguistic theory represents a viewpoint that dismisses central questions of use in the area of performance. Communicative competence is a concept introduced by Dell Hymes 


\section{English Language Proficiency and School Performance in English}

(1966) and discussed and redefined by many authors.

This study aimed to find out the Junior High School English Language Proficiency Level of the teachers and Grade 10 students of selected high schools in the $5^{\text {th }}$ district of Iloilo. The findings of the study served as basis for the enhancement of the existing English manual.

\section{METHODOLOGY}

\section{A. Research Design}

This study used the descriptive comparative method of research in determining the English Language Proficiency Level of the teachers and the students and the school Performance. This study described, analyzed, and measured the proficiency level of students and teachers.

Descriptive method was appropriate in this study because it required description of the existing conditions of the respondents with respect to the variables under consideration.

This study also explored the extent or degree of relationship among set of variables. Specifically, it investigated the level of students' and teachers' English language proficiency, as well as their school performance as a whole.

\section{B. Participants of the Study}

The respondents of the study were all secondary English teachers and the grade ten students of the national high schools in the Fifth District of Iloilo.

Presented in Matrix 1 are the respective actual numbers of grade 10 students and the distribution of student and teacher respondents (randomly selected using the Slovin's formula) from the respective national high schools in the fifth District of Iloilo.All students are officially enrolled for School Year 2015-2016; the teachers are all permanent in the respective schools.

\section{Matrix Presentation of Research Respondents}

\begin{tabular}{|c|c|c|c|c|}
\hline \multirow[b]{2}{*}{ Name of School } & \multicolumn{2}{|l|}{ Teachers } & \multicolumn{2}{|l|}{ Students } \\
\hline & $\begin{array}{l}\text { Total No. of } \\
\text { Participants }\end{array}$ & $\begin{array}{l}\text { Total No. of } \\
\text { Enrolment }\end{array}$ & $\begin{array}{l}\text { Total No. of } \\
\text { Participants }\end{array}$ & $\begin{array}{l}\text { Actual No. of } \\
\text { Participants }\end{array}$ \\
\hline $\begin{array}{l}\text { 1. Ajuy National High } \\
\text { School }\end{array}$ & 6 & 390 & 36 & 36 \\
\hline $\begin{array}{l}\text { 2. Balasan National High } \\
\text { School }\end{array}$ & 9 & 499 & 46 & 46 \\
\hline $\begin{array}{l}\text { 3. Barotac Viejo National } \\
\text { High School }\end{array}$ & 12 & 456 & 42 & 42 \\
\hline $\begin{array}{l}\text { 4. Batad National High } \\
\text { School }\end{array}$ & 4 & 160 & 15 & 15 \\
\hline $\begin{array}{l}\text { 5. Don Casimero } \\
\text { Andrada National High } \\
\text { School }\end{array}$ & 7 & 229 & 21 & 21 \\
\hline $\begin{array}{l}\text { 6. Roberto H. Tirol } \\
\text { National High School }\end{array}$ & 8 & 290 & 26 & 26 \\
\hline $\begin{array}{l}\text { 7. Estancia National } \\
\text { High School }\end{array}$ & 18 & 768 & 70 & 70 \\
\hline $\begin{array}{l}\text { 8. Lemery National High } \\
\text { School }\end{array}$ & 4 & 236 & 21 & 21 \\
\hline $\begin{array}{l}\text { 9. Nicomedes R. Tubar } \\
\text { Sr. National High School }\end{array}$ & 5 & 174 & 16 & 16 \\
\hline $\begin{array}{l}\text { 10. San Rafael National } \\
\text { High School }\end{array}$ & 6 & 254 & 23 & 23 \\
\hline $\begin{array}{l}\text { 11. Sara National High } \\
\text { School }\end{array}$ & 14 & 515 & 47 & 47 \\
\hline Total & 93 & 3965 & 363 & 363 \\
\hline
\end{tabular}


English Language Proficiency and School Performance in English

Matrix of the Different National High Schools in the Fifth District of Iloilo School Year 2014-2015

\begin{tabular}{|c|c|c|c|c|}
\hline \multirow[b]{2}{*}{ Name of School } & \multicolumn{2}{|c|}{ English Teachers } & \multicolumn{2}{|l|}{ Students } \\
\hline & $\begin{array}{l}\text { Total Number } \\
\text { of English } \\
\text { Teachers }\end{array}$ & $\begin{array}{l}\text { Actual Number of } \\
\text { English Teachers } \\
\text { Respondents }\end{array}$ & $\begin{array}{l}\text { Actual Number of } \\
\text { grade } 10 \text { enrolled } \\
\text { students }\end{array}$ & $\begin{array}{l}\text { Actual Number of } \\
\text { students Respondents } \\
\text { (Slovin) }\end{array}$ \\
\hline 1. Ajuy National High School & 6 & 6 & 390 & 36 \\
\hline 2. Balasan National High School & 9 & 9 & 499 & 46 \\
\hline $\begin{array}{l}\text { 3. Btac. Viejo National High } \\
\text { School }\end{array}$ & 12 & 12 & 456 & 42 \\
\hline 4. Batad National High School & 4 & 4 & 160 & 15 \\
\hline $\begin{array}{l}\text { 5. Don Casimero Andrada National } \\
\text { High School }\end{array}$ & 7 & 7 & 229 & 21 \\
\hline $\begin{array}{l}\text { 6. Roberto H. Tirol National High } \\
\text { School }\end{array}$ & 8 & 8 & 290 & 26 \\
\hline 7. Estancia National High School & 18 & 18 & 768 & 70 \\
\hline 9. Lemery National High School & 4 & 4 & 236 & 21 \\
\hline $\begin{array}{lll}\text { 10. Nicomedes R. Tubar } & \text { Sr. } \\
\text { National High School } & & \\
\end{array}$ & 5 & 5 & 174 & 16 \\
\hline $\begin{array}{l}\text { 11. San Rafael National } \\
\text { High School }\end{array}$ & 6 & 6 & 254 & 23 \\
\hline 12. Sara National High School & 15 & 15 & 515 & 47 \\
\hline TOTAL & 94 & 94 & 3,965 & 363 \\
\hline
\end{tabular}

All teachers were taken as respondents in the study. There is a total of Three thousand six hundred ninety-five (3,965) fourth year students of the respective national high schools in the fifth district of Iloilo. With the use of Slovin's formula, the number of student-respondents will be computed.

Stratified random sampling was used in the study. To allocate proportionately the samples of all schools covered in this study the formula by Basinang was used. The respondents per school were selected using the fishbowl technique. The names of the teachers were written on small pieces of paper and then the desired number of respondents was drawn.

Using the stratified random sampling the researcher had come up with a total of 363 high school students as respondents in the 11 national high schools in the $5^{\text {th }}$ district of Iloilo.

\section{Research Instruments}

The instruments in this research study were two questionnaires. The instrument was divided into two (2) parts: Part IStudents' and Teachers' Profile, Part II- English Proficiency Test.

\section{Data Gathering}

It was agreed during the pre-oral hearing that the instrument to be used in the study is the Language Proficiency Test administered by the DepEd but unfortunately, the said test is strictly for DepEd use only. The researcher consulted the adviser and the panel if the researcher could utilize the Proficiency Test given by the Northern Iloilo Polytechnic State College which served as the English Placement test for incoming freshmen. It was agreed that the said Proficiency Test will be used, and it was then reproduced.

Permission to conduct the study and retrieve the NCBTS files of the teacher respondents was done through official letter-request addressed to the Schools Division Superintendent of DepEd, Jaro, Iloilo City. Separate official letter-requests were made and were addressed to the respective principals of each national high school. Upon approval of the requests, the researcher personally administered the distribution of instruments to target student and teacher-respondents, one national high school at a time to obtain responses.

Similarly, the researcher requested for the respective grades of student and teacher-respondents in English proficiency, and NAT performance of schools from the school Registrar's Office through an approved letter request.

The data of student-respondents were retrieved; their grades were cross-checked correctly. All the data were encoded and presented in tabular form to facilitate the application of statistical treatment through the help of a Statistician, and results were analyzed and interpreted. 


\section{English Language Proficiency and School Performance in English}

\section{E. Treatment of Data}

In answering the research questions posed in the study, the following methods were used for the analyses and interpretations: frequency counts and percentage, mean, chi- square and Pearson r.

\section{F. Ethical Considerations}

The information taken from the student and teacher-respondents and different national high school in the fifth district of Iloilo will remain confidential and they cannot be used as evidentiary documents against anyone of them. All of the respondents are not identifiable as to their names, name of school, and other personal features. Findings of this study cannot be used against any of the student and teacher-respondents and the national high school authorities in any manner and in any litigation which may arise in the future.

\section{RESULTS AND DISCUSSION}

This chapter presents the interpretation and analysis of data gathered in this study in terms of (1) Profile of the Student-Respondents in terms of (a) Sex; (b) Number of Siblings; and (c) Combined Monthly Income of Parents; (2) Profile of Teacher Respondents' in terms of(a) Number of years in teaching English; (b) Highest educational attainment; and (c)Relevant Trainings/Seminars, (3) Student and Teacher-Respondents' Level of English Language Proficiency in terms of (a) Correct Usage; (b) Identifying Errors; (c) Vocabulary; and (d) Reading Comprehension; Performance in English of the Student and Teacher-Respondents and the NAT performance of the schools.

Generally, seventy percent of the student and teacher respondents were female.

Teachers' Level of English language proficiency has a significant effect on the level of proficiency of students which has a direct relationship on the school performance. It was also found out that teachers' performance has no significant relationship with the students' performance in English and school performance as a whole.

Further, student-respondents performance has a significant relationship with their level of English language proficiency which has a direct effect on the school performance as a whole.

\section{CONCLUSION}

The English teachers' performance is related to their English proficiency level, but not associated with the students' performance in English and school performance.

However, the English teachers' level of English language proficiency significantly affects the students' level of English proficiency, while the students' performance has a significant effect on their level of English language proficiency, affecting the school performance as a whole.

Enhancement of the English language manual that will be used in English 101 (Study and Thinking Skills) must be adopted. Training \& Development Program Design for the Enhancement of English Teachers language Proficiency must be implemented.

\section{REFERENCES}

1) Abao, E. (2013). Second Language Facility of Student Teachers in the Philippines: An Opportunity or a Challenge? Cebu Normal University, Cebu City, Philippines in European Scientific Journal: December, 2013 edition Vol. 9, No. 34 ISSN:1857-7881 (Print)e-ISSN1857- 7431193.

2) Adanza, Estela G. Bermudo, Predito Jose v., Rasonable, Marietta. (2009). “Methods of Research: A Primer". Rex Printing Company, Inc. Quezon, City pages. 133-135.

3) Agregado, Leila (2014), National Achievement Test and Language Performance .academia.edu/409203/ Evaluative_Study_of_SecondarySchool_Teachers_Competency_in_English.

4) Arshad, M. (2007-2009). Evaluative Study of Secondary School Teachers' Competency in the Subject English.In www.academia.edu/409203/Evaluative_Study_of_SecondarySchool_Teachers_Competency_in_English.

5) Bailey, K.M. (2006).Language teacher supervision: A case-based approach. New York: Cambridge University Press.

6) Brau, V. \& Clarke, V. (2006). Using Thematic Content Analysis in Psychology. Qualitative Research in Psychology, 3(2). Pp. 77-101 ISSN14780-0887 in prints.uwe.ac.uk/11735/2/thematic_analysis_revised

7) Burns, A. \& Richards, J.C..(2012). The Cambridge Guide to Pedagogy andPractice in Second Language Teaching. New York, NY: Cambridge University Press.

8) Calderon, Jose F: Gonzales, expectacion c. 1993. "Methods of Research and Thesis Writing”. National Book Store Inc. Metro, Manila page 263.

9) Canale, M. \& Swain, M. (1980). Theoretical bases of communicative approaches to second language teaching and testing. Applied linguistics, 1,1-47.Munby, J. (1978).

10) Cascallar, E. \& Henning, G. (2011). Research Reports: A preliminary study of the nature of communicative competence, 21 November 2011. 
11) Creswell, J.W. (2013). Qualitative Inquiry and Research Design-Choosingamong five approaches, $3^{\text {rded.USA: Sage }}$ Publications Inc..

12) Chomsky, Noam (1965). Aspects of the theory of syntax. Cambridge: M.I.T. Press.

13) Corpuz, I. (2013). English in High school (Mini critique) in www.philstar.com/education-ad-home/482651/english-inhigh-school.en.wikipedia.org/wiki/English_Language

14) English, A. (2007). Interrupted Experiences: Reflection, listening and "negativity" in the practice of teaching. Learning Inquiry, 1(2), 133-142.

15) Diergos F. D. (2010). “Understanding Language Assessment," London, UK: Hodder

16) Francisco, Erlyn S. (2013). NAT Performance of the National High School in the town of Carles, Unpublished, Thesis.

17) Gortayo K. (2013).Listening:Challenges for Teachers.Teachers College Record, 112(11), 2717-2727.International Journal of Research Studies in Language Learning 2014, January, Volume 3 Number 1 67-80. jalt_publications.org/files/pdf_article/plen1.pdf

18) Hymes, Dell H. (1966). “Two types of linguistic relativity”. In Bright, W. Sociolinguistics. The Hague: Mouton. pp. 114158.

19) Hymes, Dell H. (1972). “On communicative competence”. In Pride, J.B.; Holmes, J. Sociolinguistics: selected readings.

20) Khami-Stein, L.D. (2009). Teacher preparation and non-native English speaking educators. In A. Burns \& J.C. Richards (Ed) The Cambridge guide to second language teacher education (pp.91-101). Cambridge University Press.

21) Kretovics \& Nussel, I. (2005). ELT Student Teachers' Competence for Teaching Language Skills: A Qualitative Exploration. International Journal ofSocial Sciences and Humanity Studies, Vol.3, No.1 2011 ISSN:1309-8063. In www.sobiad.org/ejournals/journal_ijss/archieves/2011_1/irem_kizi laslan.pdf

22) Lane, et al.(2009). Teacher knowledge about reading fluency and indicators of students' fluency growth in reading first schools. Reading and Writing Quarterly, 25(1),57-86.

23) Lebrun, M.(2008). Communiqué ecvalementenclasse: une competence transversal. Vie pedagogique,149, 2008, 49-53 in Speaking for Excellence: Language Competencies for Effective Teaching Practice (2013).

24) Littlewood, W. (1981).Communicative language teaching: An introduction. Cambridge: Cambridge University Press.

25) Louden, W. \&Rohl, M.(2006). “Too many theories and not enough instruction” Perception of preservice teacher preparation for literacy teaching in Australian schools. Literacy, 40(2), 66-78.doi:10-1111/j.1467-9345.2006 00440x.

26) McNaughton, D. et al.(2008). Learning to Listen: Teaching an active listening strategy to pre service education professionals. Topics in Early Childhood Special education, 27(4), 223-231.

27) Nunan, D. (2009). Second Language Teaching \& Learning. Pasig City, Philippines: ESP Printers, Inc.

28) Ohno, A. (2011). Communicative Competence and Communicative Language Teaching in http://cicero.ubunkyo.acjp/lib/kiyo/fsells002/25-32.pdf.

29) Phelps, G. (2009). Just knowing how to read isn't enough! Assessing knowledge for teaching reading. Educational Assessment, Evaluation and Accountability, 21(2), 137-154.doi:10.1007/s11092-009-9070-6.

30) Rosario, T.M. \& Susano, R.1. , T. (2010).Approaches and Methods in language teaching: a description and analysis. Cambridge: Cambridge University Press. In Choudhury, A.S. (2011) Classroom roles of English language teachers: the traditional and the innovative. India: Assam University.

31) Saez, FT and Martin, JLO.(2010). Discourse Competence, Dealing withTexts in the EFL Classroom.University of Granada. In fernandotrujillo.es/wp-ontent/uploads/2010/05discourses.pdf

32) Savignon, S.J. Communicative Language Teaching for the Twenty-First Century in Celce-Murcia.(2006). Teaching English as a Second or Foreign Language $3^{\text {rd }}$ edition.Heinle\&Heinle.

33) Tudor, I. (1993). Teacher roles in the learner-centered classroom. ELT Journal, 47(1), 22-31. In Choudhury, A.S. (2011). Classroom roles of English language teachers: the traditional and the innovative. India: Assam University. www.english test.net/forum/ftopic42354.html

34) Utts, J. (2013). Cram 101 Textbook Reviews 2012 in https://books.google.com.ph/books?isbn...

35) Yase J. (2013). Extent of Implementation of ALS in Iloilo, Unpublished Research Paper, Northern Iloilo \{olytechnic State College.

36) Zwiers, J. (2007). Teacher Practices and prospective for developing academic language. International Journal of Applied Linguistics, 17(1), 93-116. Dol:10.1111/j1433-4192.2007.00135x 